\title{
EDITORIAL
}

\section{OUT OF SIGHT, OUT OF MIND? EXPOSING THE HUMAN COST OF DETENTION}

\section{Vincent Bernard, Editor-in-Chief}

The conditions in which detainees are being held and the way they are treated are worsening in several countries, while the rest of the world turns a blind eye. Life for these detainees is a nightmare. Limited resources, punitive criminal justice policies and malfunctioning judicial systems lead to a host of problems: overcrowded cells or, conversely, solitary confinement in high-security prisons; violence and drugs; torture, ill-treatment and the absence of legal safeguards; a lack of hygiene, food, care and, at the end of the day, dignity.

Although the situation varies widely between countries, the world's prison population has increased by almost $20 \%$ since 2000 , to more than 10 million $^{1}-$ equivalent to the population of Portugal. At the same time, the International Committee of the Red Cross (ICRC), which visits detention facilities all over the world, is seeing conditions of detention worsen. Several recent NGO reports, along with national and international inspections, have shown that detainees are being treated badly and that minorities are over-represented in the prison population. ${ }^{2}$ According to these reports, those detained in armed conflicts and other situations of violence are in a particularly worrying situation. Issues include

1 According to the World Prison Population List, "[t]he total prison population in Oceania has increased by almost $60 \%$ and that in the Americas by over $40 \%$; in Europe, by contrast, the total prison population has decreased by $21 \%$. The European figure reflects large falls in prison populations in Russia and in central and eastern Europe. In the Americas, the prison population has increased by $14 \%$ in the USA, by over $80 \%$ in central American countries and by $145 \%$ in south American countries." Roy Walmsley, World Prison Population List, 11th ed., Institute for Criminal Policy Research (ICPR), London, 2016, available at: www. prisonstudies.org/news/more-1035-million-people-are-prison-around-world-new-report-shows (all internet references were accessed in December 2017). See also Andrew Coyle, Catherine Heard and Helen Fair, "Current Trends and Practices in the Use of Imprisonment", in this issue of the Review.

2 See Jessica Jacobson, Catherine Heard and Helen Fair, "Prison: Evidence of Its Use and Over-Use from around the World", ICPR, 2017, available at: www.prisonstudies.org/sites/default/files/resources/ downloads/global_imprisonment_web2c.pdf; Penal Reform International, Global Prison Trends 2017, report, 2017, available at: www.penalreform.org/resource/global-prison-trends-2017/; Amnesty International, "Detention and Imprisonment", available at: www.amnesty.org/en/what-we-do/ detention/; Human Rights Watch, "Detention Centers", available at: www.hrw.org/topic/health/ detention-centers; Nils Melzer, Report of the Special Rapporteur on Torture and Other Cruel, Inhuman or Degrading Treatment or Punishment, advance edited version, UN Doc. A/HRC/34/54, 14 February 2017, available at: www.ohchr.org/Documents/Issues/Torture/A_HRC_34_54.pdf. See also the country visit reports of the Council of Europe Committee for the Prevention of Torture and Inhuman or Degrading Treatment or Punishment, available at: www.coe.int/en/web/cpt/visits\#2017. 
the detention and disappearance of minors in Afghanistan, Nigeria and Somalia, ${ }^{3}$ torture in Syria, ${ }^{4}$ and a disproportionate increase in the detention of women. ${ }^{5}$

However, few people seem to be interested in what happens to detainees, either close to home or in far-away countries. Are people immune to the slowly worsening conditions affecting one of society's most marginalized groups because their attention is dominated by a succession of high-profile disasters? Is it a general climate of fear - as well as the comfortable presumption that detainees are getting what they deserve - that makes it so easy to ignore the plight of those rotting in prison?

Unlike other categories of vulnerable people, detainees are not always regarded as human beings with rights. Their identity is reduced to the threat real or imagined - that they might pose to society. Calls for "terrorists" and "criminals" to be treated humanely while in prison tend to fall on deaf ears at a time when our attention is constantly being drawn to the security risks they pose.

Indeed, detention is not the only area in which humanitarian fundamentals are clouded by security concerns. Migrants and refugees, whether fleeing from danger or leaving their homes in search of a better life, are also seen mainly as a threat that must be contained by barbed wire and walls, or confined within camps. The increasing use of detention as a way of dealing with migrants is an issue that will be dealt with in an upcoming issue of the Review focusing on migration and internal displacement.

As Amnesty International says succinctly on its website:

It is easy sometimes to think that the rights of prisoners have little to do with us that they have somehow exchanged their rights for a life of crime. This is wrong on two counts. Firstly, everyone has the same rights and they can never be taken away, no matter where you are, or what you may have done. Secondly, just because you are in prison, it does not mean you are guilty of a crime - if you were lucky enough to have a trial, it may not have been a fair one. ${ }^{6}$

To overcome attitudes of denial and awaken people's consciences, we need to promote a different point of view - one that recognizes the human dignity of detainees, whatever the reason for their detention. Accordingly, the Review has decided to address today's detention crisis by looking at its humanitarian consequences, and to shed light on its human cost, both individual and collective.

3 See ICRC, Children in Detention, report, 24 February 2017, available at: www.icrc.org/en/publication/ 4201-children-and-detention; Human Rights Watch, "Children Detained in War Zones: Thousands Held Without Charge, Tortured", 28 July 2016, available at: www.hrw.org/news/2016/07/28/childrendetained-war-zones.

4 See Amnesty International, "End the Horror in Syria's Torture Prisons", available at: www.amnesty.org/ en/latest/campaigns/2016/08/syria-torture-prisons/.

5 See, Roy Walmsley, World Female Imprisonment List, 4th ed., ICPR, London, 9 November 2017, available at: www.prisonstudies.org/news/world-female-imprisonment-list-fourth-edition; Elizabeth Swavola, Kristin Riley and Ram Subramanian, Overlooked: Women and Jails in an Era of Reform, report, Vera Institute of Justice, New York, 2016; Anita Chabria, "China: Women Prisoner Numbers Rise 10 Times Faster than Men”, International Drug Policy Consortium, 27 August 2015, available at: http://idpc.net/ alerts/2015/08/china-women-prisoner-numbers-rise-10-times-faster-than-men.

6 Amnesty International, "Detention and Imprisonment", available at: www.amnesty.org/en/what-we-do/ detention/. 
Accordingly, this issue begins with a presentation of prisoner art on display at the International Red Cross and Red Crescent Museum in Geneva. The photos convey the humanity of the people who made these works of art using whatever materials they had to hand.

The Review has already dedicated an issue to the subject of detention in 2005, ${ }^{7}$ and still publishes regular articles on the subject. Historically, the ICRC's work in places of detention has mainly concerned people being held in the context of armed conflict and other situations of violence. In many situations today, however, the ICRC takes humanitarian action to improve the welfare of all detainees, whatever the reason for their arrest or detention. In this issue of the Review, we take the same approach.

Over the years, new trends have emerged and certain pre-existing situations have worsened with respect to prisons: increasing overcrowding, rising drug use, an ageing population and greater use of solitary confinement. This issue of the Review addresses some of these trends and, as in 2005, looks at the ill-treatment and torture of detainees. There are also positive developments that need to be shared, such as the adoption in 2015 by the United Nations General Assembly of the new revised Standard Minimum Rules for the Treatment of Prisoners, also known as the Nelson Mandela Rules); ${ }^{8}$ the professionalization of the prison service, particularly in Africa; ${ }^{9}$ the development of innovative prison systems; ${ }^{10}$ and efforts to reduce overcrowding in some contexts. ${ }^{11}$

\section{The costs of detention}

As well as an economic cost, detention has physical, mental, emotional and moral costs. Those costs are individual and collective, direct and indirect, short- and long-term.

7 Thematic issue on "Detention", International Review of the Red Cross, Vol. 87, No. 857, 2005.

8 See: ICRC, "Better protection for detainees", 14 February 2016, available at www.icrc.org/en/document/ better-protection-detainees and United Nations Standard Minimum Rules for the Treatment of Prisoners (the Mandela Rules), UN Doc. A/C.3/70/L.3, 29 September 2015, available at: www.un.org/ ga/search/view_doc.asp?symbol=A/C.3/70/L.3.

9 As evidence of this, in 2008, the African Correctional Services Association was formed. Formerly the Conference of Eastern, Southern and Central African Heads of Corrections, this organization holds conferences aimed at allowing penitentiary professionals in Africa to exchange ideas with one another. See: www.africancorrectionalservicesassociation.org/index.php.

10 In the United States see: Lindsey Cramer, "9 Innovative Ways to Fix Our Broken Prison System", Mic, 17 December 2013, available at: https://mic.com/articles/76771/9-innovative-ways-to-fix-our-broken-prisonsystem\#.hUXNemvz8. In Norway, see: Marianne Vollan, "Full Rights Citizens: The Principle of Normality in Norwegian Prisons", Justice Trends, No. 1, 2017, available at: www.eu-training.com/justicetrends/ flipbook/flipbook/index.html?page=36. In Portugal, see: Celso Manata, "Challenges and Achievements of the Portuguese Correctional System", Justice Trends, No. 1, 2017, available at: www.eu-training.com/ justicetrends/flipbook/flipbook/index.html?page=50. The New Penitentiary Model in the Dominican Republic is discussed at: Ysmael Paniagua, "Dominican Republic: An Example of Penitentiary Reform to Be Followed", Justice Trends, No. 1, 2017, available at: www.eu-training.com/justicetrends/flipbook/ flipbook/index.html?page $=138$.

11 For examples in Kenya and the Democratic Republic of the Congo, see: Africa Criminal Justice Reform, "Plans to Decongest Kenyan Prisons via Clemency", available at: http://acjr.org.za/news/plans-to-decongest-kenyanprisons; Graham Kajilwa, "Petty Offenders to Be Released in Bid to Decongest Kenya Prisons", Standard Digital, 4 October 2016, available at: www.standardmedia.co.ke/article/2000218320/petty-offenders-to-bereleased-in-bid-to-decongest-kenya-prisons; "Democratic Republic of Congo to Release 2,000 Prisoners to Reduce Overcrowding in Jails", Reuters, 5 January 2016, available at: www.standardmedia.co.ke/article/ 2000187118/democratic-republic-of-congo-to-release-2-000-prisoners-to-reduce-overcrowding-in-jails. 
Of course, the main human cost of detention is borne by the detainees themselves. As well as being deprived of their liberty and usually any kind of normal social and family life - which is the normal definition of detentiondetainees often experience other types of suffering that are not justified by any reasons relating to social order or security.

For example, they may be victims of violence by other detainees or guards. Instances of sexual violence are particularly intolerable. ${ }^{12}$ Inmates may also be deprived of health care or food because of corruption, incompetence or a lack of resources in the prison administration, among other reasons. They may be held for extended periods before they are sentenced because of the slow pace of court proceedings. Imprisonment is also a punishment that is too often used in cases where milder alternatives could be applied, particularly for less serious offences.

The individual costs of imprisonment are worse for the most vulnerable categories of prisoners, particularly minors but also the elderly. The number of older adults in prison has surged in the last few years. In the UK, for example, the total prison population grew $51 \%$ between 2000 and 2009, while the number of prisoners aged over 60 soared by $216 \%$. There is now talk of a real crisis: prison care services are unsuited to dealing with older people, since prisons were generally designed to hold the young. ${ }^{13}$

Two other current phenomena, while seemingly contradictory, are particularly worrying: prison overcrowding on the one hand, and increasing use of solitary confinement on the other. Overcrowding has serious consequences in terms of hygiene, physical and mental health, and levels of violence.

Solitary confinement, which in the past was used for disciplinary purposes, is becoming more common and is sometimes the default option, with people being held in solitary for long periods in "supermax" high-security prisons. Detainees are sometimes prevented from communicating with the outside world. As Catherine Deman said with regard to solitary confinement at a conference at the Humanitarium in Geneva:

It may be because they are considered dangerous, it may be for interrogation or punishment, as a consequence of their sentence or sometimes even for their own safety. But whatever the reason, such isolation can entail enormous suffering and have very severe human consequences. ${ }^{14}$

The level of control applied to detainees' contact with the outside world should be strictly in proportion to need, and to the real and present danger that such contact could create.

12 See thematic issue on "Sexual Violence in Armed Conflict", International Review of the Red Cross, Vol. 96, No. 894, 2014, notably “Through the Eyes of a Detention Doctor: Interview with Raed Aburabi”; and Paul Bouvier, "Sexual Violence, Health and Humanitarian Ethics: Towards a Holistic, Person-Centred Approach".

13 See Rachel Bedard, Lia Metzger and Brie Williams, "Ageing Prisoners: An Introduction to Geriatric Health-Care Challenges in Correctional Facilities", in this issue of the Review.

14 In the context of the annual cycle of conferences that the ICRC organizes on certain Review themes, see the web page for the ICRC event on "Solitary Confinement: How to Preserve Humanity in High-Security Settings", available at: www.icrc.org/en/event/solitary-confinement-how-preserve-humanity-highsecurity-settings. 
Since 1787 and Jeremy Bentham's concept of the Panopticon, ${ }^{15}$ prisons have also been spaces defined by architecture and technology, which can either compound or reduce the costs of detention for individuals. Bentham conceived of the Panopticon as a building that allows the total, permanent surveillance of a large number of inmates at minimal cost. Architecture can thus serve to make prisons more oppressive and punitive or, on the contrary, to promote rehabilitation and reintegration. Today, thinking about the role of architecture in detention continues to evolve. Can an architect, in good conscience, design solitary confinement cells if using them amounts to torture? The way in which architects deal with these ethical questions is currently a matter of debate. ${ }^{16}$ Digital technology is also being used to reveal the secrets behind the most closely guarded prisons, for example as part of the Amnesty International and Forensic Architecture project to digitally reconstruct the Sadnaya prison. ${ }^{17}$

Naturally, imprisonment also has a cost for the prisoners' loved ones, who may be traumatized and stigmatized, as well as suffering a loss of income. Prisoners' children pay a particularly heavy price. ${ }^{18}$

Furthermore, economic, social and moral costs should be taken into account. For the community, the imprisonment of productive individuals creates a shortfall of resources, and there is also the cost of maintaining and developing prisons, including the huge cost of adapting prison services and infrastructure to deal with the growing number of elderly prisoners.

Often, the authorities do not allocate sufficient budgets to prison administrators. Prison services also suffer from lack of adequate management structures and planning. However, the prison system is supposed to reintegrate people into society, where other institutions such as education, the family and welfare may have failed. Without enough money to deal with inmates in a humane way, prisons become a breeding ground for violence, trafficking and indoctrination. Increasingly, detention becomes part of the problem that it is supposed to solve. ${ }^{19}$

15 Jeremy Bentham, The Panopticon Writings, 1798, in The Works of Jeremy Bentham, ed. John Bowring, Vol. 4, 1843, available at: http://oll.libertyfund.org/titles/bentham-the-works-of-jeremy-bentham-vol4\#1f0872-04_head_004.

16 See Whitney Mallett, "Is It Ethical for Architects to Build Solitary Confinement Cells?", Motherboard, 7 January 2015, available at: https://motherboard.vice.com/en_us/article/qkvezb/architects-code-of-ethics.

17 Forensic Architecture, "Sadnaya: Inside a Syrian Torture Prison", available at: www.forensic-architecture. org/case/saydnaya/.

18 See Megan Comfort, Tasseli McKay, Justin Landwehr, Erin Kennedy, Christine Lindquist and Anupa Bir, "The Costs of Incarceration for Families of Prisoners", in this issue of the Review.

19 Michel Foucault summed up the criticisms of twentieth-century prisons: (1) "Prisons do not diminish the crime rate"; (2) "Detention causes recidivism"; (3) "The prison cannot fail to produce delinquents"; (4) "The prison makes possible, even encourages, the organization of a milieu of delinquents, loyal to one another, hierarchized, ready to aid and abet any future criminal act"; (5) "The conditions to which the free inmates are subjected necessarily condemn them to recidivism"; and (6) "The prison indirectly produces delinquents by throwing the inmate's family into destitution". Michel Foucault, Discipline and Punish: The Birth of the Prison, trans. Alan Sheridan, Random House, New York, 1977 pp. $265-268$. 
The risk of prisoners being radicalized and recruited into criminal groups that make use of terror is one that has been highlighted in the last few years. In response, States are developing policies that aim to prevent radicalization, and to promote "de-radicalization", in prisons. Those policies pose a series of problems: for example, certain inmates may be isolated and treated more severely, without clear criteria explaining why. The ICRC has expressed its concern about these policies in a recent document. It stated that "inhumane conditions of detention and treatment not only contradict State obligations but are highly counterproductive to any efforts to prevent 'radicalization' and violent extremism". ${ }^{20}$

Finally, focusing mainly on measures of detention and repression to address societal issues has an opportunity cost: it can limit the space for more effective measures and policies, especially for vulnerable populations (detained migrants, children in conflict, low-risk offenders, and so on). Generally speaking, objectively assessing the impact on individuals and society of existing detention policies is necessary to avoid further human, social, political and financial costs.

\section{Detention in conflicts}

In a conflict situation, international humanitarian law (IHL) lays down rules for the detention of people in the power of the enemy. The treaties are fairly detailed regarding international armed conflicts; the Geneva Conventions contain over 175 articles about detention. Having already published the updated commentaries on the first two Geneva Conventions, the ICRC is currently working on an update to the Commentary on the Third Geneva Convention relative to the Treatment of Prisoners of War of 1949, which is set to be published in 2019. There are significantly fewer treaty rules regarding detention in relation to noninternational armed conflicts, which currently make up the majority of conflict situations. Detainees in a conflict situation are particularly vulnerable because they are in the hands of their "enemy", be that a State, an armed group or multinational forces. While national law and international human rights rules continue to apply, they sometimes fail to take into account the reality of conflict, for example the possibility of civilians being interned for security reasons. In recent years, the European Court of Human Rights has made several rulings on the legality of extraterritorial detention practised by certain States in armed conflicts, on the basis of the European Convention on Human Rights (ECHR), without always regarding IHL as the lex specialis-i.e., the specific law that applies to conflicts. In the Review, Claire Landais and Léa Bass have expressed the following concern shared by many specialists regarding this European case law: 
Yet while there is no question that the increasingly important place given to European human rights law in times of extraterritorial armed conflict extends the protections afforded to individuals, a too strict application of its rules could impose unrealistic obligations on States in this type of situation. In the long term, this could make them less inclined to comply with the law, and possibly with more basic rules of other branches of law, in particular with rules of IHL. ${ }^{21}$

Those authors instead suggest interpreting the ECHR in light of IHL.

The international community also clearly recognized the need to strengthen IHL rules that protect detainees in times of armed conflict, particularly non-international armed conflict, at the 31st and 32nd International Conferences of the Red Cross and Red Crescent. ${ }^{22}$ As explained in this issue's contribution by ICRC Legal Adviser Tilman Rodenhäuser, the ICRC has identified - and States have recognized - four areas in which IHL should be strengthened: (1) conditions of detention, (2) the protection of the most vulnerable persons, (3) grounds and procedures for internment, and (4) transfers of persons deprived of their liberty. ${ }^{23}$ Unfortunately, despite major initiatives by States and international organizations, and the ICRC's own work as mentioned above, progress has been insufficient. ${ }^{24}$

In armed conflict situations, detention is a legitimate way of ensuring that an enemy cannot cause harm. Once enemies have put down their weapons, they must be treated in accordance with the applicable national and international law. During hostilities, ordering that no quarter will be given, meaning that no survivors remain, is prohibited under IHL. However, there is a dangerous tendency for States to make frequent use of "targeted assassinations" extrajudicial executions - when combating groups deemed to be terrorists, even where arresting them would be an option. The killing of suspects also deprives victims, society and history of the benefits of due process, and so denies them the possibility of establishing the facts, obtaining justice and healing wounds.

21 Claire Landais and Lea Bass, "Reconciling the Rules of International Humanitarian Law with the Rules of European Human Rights Law”, International Review of the Red Cross, Vol. 97, No. 900, 2015, p. 1296. In a previous issue of the Review, Jelena Pejic has evoked the problem posed by the jurisprudence of the European Court of Human Rights when it decided to rely not on the Geneva Conventions but rather on national law and the European Convention on Human Rights in its judgments on the legality of the detention of a civilian by British armed forces in Iraq. Jelena Pejic, "The European Court of Human Rights' Al-Jedda Judgment: The Oversight of International Humanitarian Law”, Vol. 93, No. 883, 2011.

22 "31st International Conference 2011: Resolution 1 - Strengthening Legal Protection for Victims of Armed Conflicts", available at: www.icrc.org/eng/resources/documents/resolution/31-international-conferenceresolution-1-2011.htm.

23 ICRC, "Strengthening Legal Protection for Persons Deprived of their Liberty in relation to NonInternational Armed Conflict: Regional Consultations 2012-13", Background Paper, 2013, available at: www.icrc.org/eng/assets/files/2013/strengthening-legal-protection-detention-consultations-2012-2013icrc.pdf.

24 See Tilman Rodenhäuser, "Strengthening IHL Protecting Persons Deprived of Their Liberty: Main Aspects of the Consultations and Discussions since 2011", in this issue of the Review. 


\section{Torture and the neo-barbarians}

Since the Roman Empire, each era has had its barbarians: people - always distant others - who are savage, cruel and violent. Barbarism is an affront to civilization, progress and reason. Today, it is personified by terrorists, the new hostis humani generis. ${ }^{25}$ However, although barbarism is defined by the absence of humanity, it takes many forms and is not always as distant as we may think. Totalitarian regimes in the twentieth century showed that smooth but unscrupulous politicians, zealous public servants and innovative engineers can also be barbaric. In the era of the Internet and globalization, barbaric attitudes can now be expressed on social media. Barbarism can be cloaked by politically correct expressions such as "enhanced interrogation techniques". Engaging in a pseudodebate about the "effectiveness" of torture is an example of this white-collar barbarism.

We are seeing a steady stream of new apologists for torture. However, the Convention against Torture and Other Cruel, Inhuman or Degrading Treatment or Punishment, adopted on 10 December 1984, now has 162 State signatories. Under the rule of law, the end never justifies the means. ${ }^{26}$

As Brad Guterres et al. wrote in a previous issue of the Review, concerning the TV series 24 , the media can have a harmful influence on the popular perception of torture. ${ }^{27}$ Usually, films and TV series are at best neutral and at worst complacent regarding detention conditions and torture. In the film Zero Dark Thirty (2013), which deals with the hunt for Osama bin Laden, the heroine looks on impassively as an agent tortures detainees, without qualms and in a "professional" manner. The film's characters, and viewers, had probably had their consciences numbed by more than a decade of terrorist and counterterrorist activities.

A recent ICRC survey entitled People on $\mathrm{War}^{28}$ conducted across sixteen countries, shows that no fewer than $36 \%$ of respondents believe it is acceptable to torture captured enemy combatants in order to extract important military information from them. Only $48 \%$ of those surveyed were against the practicedown from $66 \%$ in a similar survey in 1999 - while $16 \%$ had no views on the subject.

Responding to the survey, ICRC President Peter Maurer said that

torture in any form is forbidden. We demonize our enemies at our own peril. Even in war, everyone deserves to be treated humanely. Using torture only

25 See, for example, Douglas R. Burgess Jr, "Hostis Humani Generi: Piracy, Terrorism and a New International Law", University of Miami International and Comparative Law Review, Vol. 13, No. 2, 2006, available at: https://repository.law.miami.edu/umiclr/vol13/iss $2 / 2 /$.

26 For a discussion on the role of torture today and efforts to prevent it, see ICRC, "Old Pain, New Demons: Thinking Torture and Dignity Today", 2017, available at: www.icrc.org/en/document/old-pain-newdemons-thinking-torture-and-dignity-today.

27 Brad Gutierrez, Sara DeCristofaro and Michael Woods, "What Americans Think of International Humanitarian Law", International Review of the Red Cross, Vol. 93, No. 884, 2012, pp. 1016-1019.

28 ICRC, People on War: Perspectives from 16 Countries, report, 2016, available at: www.icrc.org/en/ document/people-on-war. 
triggers a race to the bottom. It has a devastating impact on the victims, and it brutalizes entire societies for generations. ${ }^{29}$

A recent study by the Association for the Prevention of Torture confirmed that a holistic approach to preventing torture can be effective. ${ }^{30}$ In their article in this issue of the Review, Jonathan Austin and Riccardo Bocco look at why torture takes place and suggest new approaches to prevent people from practising torture, focusing on helping potential torturers among the police and other weapons-bearers to hold onto their humanity. ${ }^{31}$

\section{The ICRC in places of detention}

In the first few decades of the ICRC's existence, its activities with respect to people deprived of their liberty focused on prisoners of war and civilian internees in international conflicts, for which it eventually received a mandate from the international community enshrined in the Geneva Conventions. ${ }^{32}$ Although the ICRC visited political prisoners in Hungary for the first time in April 1919, it was not until after the Second World War that it really started working for the welfare of other types of detainees in non-international armed conflicts and other situations of violence, mainly on the basis of its recognized humanitarian "right of initiative". ${ }^{33}$

In this issue of the Review, Andrew Thompson writes about a key moment in the development of the ICRC's humanitarian work in prisons: visits to Nelson

29 ICRC, "Global Survey Reveals Strong Support for Geneva Conventions but Growing Indifference to Torture", News Release, 5 December 2016, available at: www.icrc.org/en/document/global-surveyreveals-strong-support-geneva-conventions-growing-indifference-torture.

30 Association for the Prevention of Torture, "Yes, Torture Prevention Works' - Insights from a Global Research Study on 30 Years of Torture Prevention”, study, September 2016, available at: www.apt.ch/ content/files_res/apt-briefing-paper_yes-torture-prevention-works.pdf. See also the book review by Olivier Chow of Does Torture Prevention Work?, a book based on this study, in this issue of the Review.

31 See Riccardo Bocco and Jonathan Austin, "Becoming a Torturer: Towards a Global Ergonomics of Care", in this issue of the Review.

32 In 1870-71, during the Franco-Prussian war, the ICRC did this via the office of the Central Tracing Agency in Basel, which supplied prisoners of war with food and mail. This agency was the continuation of agencies in Trieste (1877-78, during the Russo-Turkish War) and Belgrade (during the 1912-13 Balkan Wars). In August 1914, the ICRC created the International Prisoners of War Agency, which remained active after the First World War. A "civilian" section was established within the Agency, largely for the benefit of civilian internees. The belligerent States generally accepted that interned enemy civilians were a subset of prisoners of war (PoWs). The first ICRC visit to prisoners of war dates back to the First World War, with ICRC president Gustav Ador's visit to German PoWs in France in December 1914. In 1921, the International Conference of the Red Cross charged the ICRC with elaborating a preliminary draft of a convention protecting PoWs, deportees, evacuees and refugees. On 27 July 1929, the Geneva Convention relative to the Treatment of Prisoners of War was adopted. See: ICRC, The International Prisoners-of-War Agency: The ICRC in World War One, Geneva, 2007, available at: https://shop.icrc.org/l-039-agence-internationale-des-prisonniers-de-guerre-le-cicrdans-la-premiere-guerre-mondiale.html; Philippe Abplanalp, "The International Conferences of the Red Cross as a Factor for the Development of International Humanitarian Law and the Cohesion of the International Red Cross and Red Crescent Movement", International Review of the Red Cross, Vol. 77, No. 815, 1995, available at: www.icrc.org/eng/resources/documents/article/other/57jmr9.htm.

33 Alain Aeschlimann, "Protection of Detainees: ICRC Action behind Bars", International Review of the Red Cross, Vol. 87, No. 857, 2005. 
Mandela and his fellow detainees in apartheid-era South Africa. ${ }^{34}$ This issue also contains a report, taken from the ICRC Archives, about the visit to Robben Island that took place on 1 May 1964, which was sent to the South African authorities and was confidential at the time. ${ }^{35}$

In 2016, the ICRC visited 1,650 places of detention in ninety-eight countries. However, these figures do not reflect the painstaking work needed to obtain official authorization and to build confidence and personal relationships with detainees and prison staff, or the empathy and other human qualities of the teams that visit prisons. Vincent Ballon, Head of the ICRC's Unit for Persons Deprived of Liberty, writes about prison overcrowding in this issue, conveying the sensory experience of a prison visit. ${ }^{36}$ The ICRC also works with States and groups of experts to identify solutions to today's humanitarian problems. For example, in 2016 the ICRC organized a workshop entitled "Ageing and Imprisonment: Identifying and Meeting the Needs of Older Prisoners" to discuss the needs of elderly prisoners and the steps that can be taken to meet them.

The ICRC's detention visits do not just take place in State facilities - the organization also strives to visit people detained by armed groups. For example, the filmed conversation between former US Army pilot Mike Durant and former ICRC delegate Suzanne Hoffstetter gives an insight into the role played by the ICRC. They discuss Hoffstetter's visits to Durant while he was being held by a Somali armed group: Durant was captured during the military operation in Mogadishu that was the subject of the film Black Hawk Down. ${ }^{37}$

Minimizing the costs of detention requires a holistic response, and humanitarian action has obvious limitations. There are few organizations doing this work, and it is not their job to take the place of governments or make up for governmental shortcomings. The response must come primarily from the detaining authorities themselves.

The ICRC knows the extent of the challenges facing prison administrators, who are being asked to implement complex policies, handle increasing numbers of prisoners and meet the apparently contradictory objectives of ensuring security and reintegrating prisoners, all without always having the required resources. For this issue, we sought contributions from prison authorities in the Philippines, Peru

34 See Andrew Thompson, “"Restoring Hope Where All Hope Was Lost': Nelson Mandela, the ICRC and the Protection of Political Detainees in Apartheid South Africa", in this issue of the Review.

35 See the ICRC report on the visit to "Robbeneiland" (Robben Island) Prison on 1 May 1964 by $\mathrm{Mr}$ G. Hoffmann, Delegate-General of the International Committee of the Red Cross in Africa, reproduced in this issue of the Review.

36 See Vincent Ballon, "Overcrowding: Nobody's Fault? When Some Struggle to Survive Waiting for Everyone to Take Responsibility", in this issue of the Review. See also Paul Bouvier, "Humanitarian Care and Small Things in Dehumanized Places", International Review of the Red Cross, Vol. 94, No. $888,2012$.

37 "Providing Hope in Detention: Interview with Michael Durant", Restoring Family Links Blog, 3 September 2015, available at: http://restoringfamilylinksblog.com/blog/providing-hope-in-detention-interview-withmichael-durant. 
and Niger. In an exceptionally candid interview, Niger's General of Police and Head of its Central Counterterrorism Agency, Abdoulaye Kaka, gives us his unvarnished opinion about his role and the challenges he faces, but also suggests some practical solutions. These matters form part of the constructive dialogue that the ICRC seeks to build with prison authorities everywhere it operates.

As Sadako Ogata said, "[t]here are no humanitarian solutions to humanitarian problems", ${ }^{38}$ and the same is true of the prisons crisis. The human costs of detention, both individual and collective, are often linked to the other, financial costs that authorities are unwilling to incur on behalf of a group of people who are out of sight. This short-termist calculation has serious implications for prisoners today, and for our societies in the future.

The Review wants to pass on the increasing concern felt by ICRC delegates - as well as among the authorities, humanitarians and members of civil society who know first-hand what really happens in prisons - about worsening prison conditions around the world. These concerns are often shared by the prison authorities themselves: their budgets are being frozen or cut at a time when the number of inmates is constantly rising. The Review hopes that it can draw attention to detention as an ongoing humanitarian challenge. To achieve that, we must ensure that society sees detainees as human beings.

38 Vivian Tan, "Ogata Calls for Stronger Political Will to Solve Refugee Crises", UNHCR, News Release, 27 May 2005, available at: www.unhcr.org/news/latest/2005/5/4297406a2/ogata-calls-stronger-politicalsolve-refugee-crises.html. 